\title{
Como vejo a medicina e os médicos
}

\author{
Edson de Oliveira Andrade ${ }^{*}$
}

Ser médico nunca foi tarefa fácil. Sempre se exigiu do indivíduo, não importando o tempo e as circunstâncias sociais envolvidas, que pretendesse exercer o ofício de médico um talhe social diferenciado. Se no princípio éramos tidos e aceitos como intermediários entre os homens e os deuses, o que originou parte do conceito de ser a Medicina um sacerdócio, hoje nos é cobrado o papel de depositários de um desejado, por infinito, conhecimento científico que vence todas as doenças e afasta o inevitável e derradeiro confronto da humanidade individual: a morte. E tudo isso em apenas um único ser humano.

Companheira do homem em sua jornada terrestre, a Medicina tem sido responsável por grande parte do sucesso alcançado pela humanidade na melhoria da qualidade e quantidade de vida experimentada pelo homem. Nos últimos anos, seus avanços ajudaram a duplicar o tempo médio de vida: dos 35 anos de vida previstos na sociedade industrial inglesa do início do século passado passamos para os 65 anos previstos atualmente para o nosso Brasil. Junto a este tempo adicional de vida agregou-se qualidade pelo controle das doenças.

Mas Medicina não é apenas números e estatísticas. Medicina é e sempre será sentimento e arte. Sentimento que nasce do indissociável compromisso de solidariedade com o homem. Arte que aflora da sensação de que o conhecimento científico não encerra em si toda a natureza do nosso ofício. A Medicina transcende ao óbvio tecnicismo, é muito mais que um desejo de conhecimento: é um sonho de transformação. E nós, médicos, somos apenas guardiões deste sonho.

Como um guardião de tão belo patrimônio deve se comportar em sua defesa é questão posta a todos nós, médicos brasileiros. Aos médicos são exigidos três níveis de comportamento. Um médico estará incompleto se descurar do necessário aprimoramento técnico. $O$ saber, primeira exigência de qualidade profissional, dá ao médico as primeiras pedras do alicerce onde se assenta o prestígio e a respeitabilidade da profissão. Tarefa difícil, permanente e em constante mutação, nos exige esforço persistente e imorredouro. Como estímulo a este árduo e necessário trabalho, cabe lembrar que o conhecimento liberta e o conhecimento médico mais, transforma.

Mas o conhecimento médico não é apenas um deleite do espírito humano; ele é transformador por ser um instrumento de trabalho, uma ferramenta operativa, um arado a abrir sulcos na terra e a plantar esperanças. Assim, deve o médico ser operante; ser um trabalhador; ser a mão que segura o arado e, se preciso, como um dia Oswaldo Cruz o foi, a mão que guia, o próprio arado e a força motriz que abre as veias por onde deverão passar livres os sonhos de um futuro melhor e mais justo. É preciso saber, e com o saber, fazer.

Ser médico não é tarefa fácil. Qualquer outra profissão já estaria satisfeita preenchendo estas duas exigências anteriormente detalhadas. Mas a nossa história sobre a Terra nos impõe outro compromisso: o saber ser. Ator social ímpar, companheiro constante, o médico é historicamente tido como um paradigma. Seus atos não são e nunca serão vistos e avaliados em igualdade de condições com as demais profissões. De quem se espera mais, se cobra mais. Penso que não exista neste comportamento social nenhum tratamento prejudicial ao médico, trata-se apenas do reverso da moeda de privilégios de que dispomos. $\mathrm{E}$ antes que o leitor interrompa a leitura por indignado com a afirmação de privilégios contida no texto, deixe-me dizer que também me indigno, e luto, contra as políticas de saúde que desconsideram o nosso papel profissional e aviltam o nosso trabalho; mas não há como confundir políticas de governo com a sociedade, nem tampouco extratos sociais com o todo social - estas são sempre transitórias e estão ao sabor das conveniências.

Voltando ao fio da meada, falo de privilégios como ter acesso pleno ao corpo das pessoas, ter conhecimento dos seus mais íntimos segredos pessoais e poder interferir em suas vidas ao ponto de modificá-las em sua totalidade. Quem detém tamanhos privilégios por certo tem iguais responsabilidades sociais. Desta forma, o guia do arado não pode ser qualquer um, tem que ser alguém especial, não melhor ou maior que os outros, mas magnificamente especial.

Ser médico é algo extremamente complexo, porém necessário. É algo arriscado, porém preciso. É algo difícil, porém possível. É algo sofrido, porém fonte de felicidade para quem gosta de gente e de observar no outro o sonho de ver em cada um a extensão de sua própria humanidade.

Este artigo é uma insuficiente homenagem a incontáveis médicos, famosos e anônimos, que fizeram destes compromissos o alicerce onde se assenta a cidadela da Medicina, e especialmente a Mário Rigatto que me ensinou a ver a Medicina como fonte inesgotável de felicidade e ventura.

\footnotetext{
* Presidente do Conselho Federal de Medicina

Contato: edsonandrade@cfm.org.br
} 